Seville was once the unofficial capital of Spain's opulent New World empire, but it failed to become a financial metropolis. The former colonial backwater Hong Kong, however, defied the odds by growing into a major trading centre. Why is it that some cities seemingly destined to become financial capitals fail to realize their potential? What are the key factors distinguishing cities that become wealthy from those that don't?

In The Evolution of Great World Cities, Christopher Kennedy examines how geography, technology, and especially the infrastructure of urban economies allow cities to develop and thrive. His investigation revolves around case studies of large cities - including Venice, Amsterdam, London, and New York City - focusing on important junctures in their histories. Kennedy weaves together insights from urbanists such as Jane Jacobs and economists such as John Maynard Keynes, drawing striking parallels between the functioning of ecosystems and of wealthy capitals. The Evolution of Great World Cities offers an illuminating introduction to urban economies that will change the way you think about cities.

CHRISTOPHER KENNEDY is a professor in the Department of Civil Engineering at the University of Toronto. 
This page intentionally left blank 


\section{CHRISTOPHER KENNEDY}

\section{The Evolution of \\ Great World Cities}

\section{Urban Wealth and Economic Growth}

UNIVERSITY OF TORONTO PRESS Toronto Buffalo London 
(C) Christopher Kennedy 2011

Rotman-UTP Publishing

University of Toronto Press

Toronto Buffalo London

www.utppublishing.com

Printed in Canada

ISBN 978-1-4426-4273-7 (cloth)

ISBN 978-1-4426-1152-8 (paper)

(\$)

Printed on acid-free, $100 \%$ post-consumer recycled paper with vegetable-based inks.

\section{Library and Archives Canada Cataloguing in Publication}

Kennedy, Christopher, 1969-

The evolution of great world cities : urban wealth and economic growth / Christopher Kennedy.

Includes bibliographical references and index.

ISBN 978-1-4426-4273-7 (bound) ISBN 978-1-4426-1152-8 (pbk.)

1. Urban economics. I. Title.

HT151.K46 2011 330.9173'2 C2011-903097-7

University of Toronto Press acknowledges the financial assistance to its publishing program of the Canada Council for the Arts and the Ontario Arts Council.
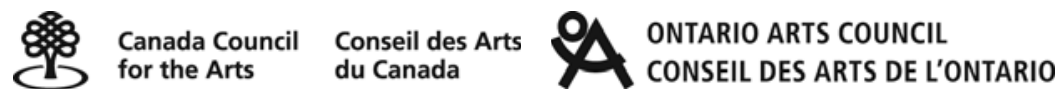

University of Toronto Press acknowledges the financial support of the Government of Canada through the Canada Book Fund for its publishing activities. 
To Denise, William, and Clarisse 
This page intentionally left blank 